\title{
Impact of Selected Variables on Stock Price With reference to Nepalese Commercial Banks
}

\author{
Bashu Neupane \\ Lecturer, Nepal Commerce Campus, T.U.
}

\begin{abstract}
This study is entirely based on secondary sources of data. The data has been collected from the Nepal Stock Exchange (NEPSE). The descriptive and analytical research designs have been used to analyze the sample. The data has been examined to determine the financial health of Nepalese commercial banks. Financial ratios help in predicting the stock price. The twenty-seven commercial banks are taken as a sample for the study. The information and data has been collected for the year 2065/066. The independent variables earning per share, price earning ratio, dividend per share, return on equity and book value per share and the dependent variable is market price per share. The financial ratios have been collected from the financial statements of the sample banks and NEPSE. The theoretical framework determines the dependent variable and independent variables. Hence, this event has been used to analyze the financial ratio and variables as independent variables to predict the dependent variable e.g., stock price.
\end{abstract}

In this research five independent variables has been used e.g., price earnings ratio, earning per share, dividend per share, return on equity, and book value per share with the dependent variable e.g., stock Price. The descriptive statistics, correlation analysis and multiple regression models is used to states the impact of independent variables on dependent variable empirically. These models are used as a strong tool to establish and find if the relationship or correlation exists between the variables. This research also throws light on the ratios can help to predict the stock return for the next period. Results give a clear indication that the P/E Ratio and EPS have the positive impact on the stock price in the NEPSE. The Nepalese investors can rely on the price earnings ratio and the earning per share to predict the market price per share. Hence, the overall conclusion of this research is that the financial variables direct the investors in NEPSE. If the answer is yes investors can rely on P/E ratio and EPS on the confidence level is 99 percent and significance level is below 0.01 which gives clear indication that price earnings ratio and earning per share may influence the stock price of commercial banks in Nepal.

Keywords: Stock price (MPS), Price-earnings (P/E) ratio, Earning per share (EPS), Return on equity (ROE), Dividend per share (DPS), and Book value per share (BPS). 


\section{Introduction}

Financial variables are the most important tools for assessing and analyzing the financial performance of any firm. It helps to compare and analyze the firm's overall financial health of an organization based on the various financial ratios. The different stakeholders can use financial ratios to get an insight into the firm's stock price. Thus, historical data are used from financial statements; financial ratios help in forecasting the firm's future health. They also help to compare and contrast the financial performance of firms among their competitors. The researches exploring this relationship have led to limited success owing largely to the existence of variability in the stock market. The variance in the volatility of these markets makes it difficult to obtain a uniform measure. A volatile stock market makes it difficult for the accounting and financial variables to accurately predict the stock price (Feris \& Erin, 2018).

A role of a stock exchange is to ensure that the companies are able to raise the required funds. Financial ratio a powerful tools to interpret the financial information that can help investors make a decision whether to invest in the company's stock or not. However, every market is unique, making it difficult to use the accepted variables across markets as stock price predictor. Additionally, ratios can efficiently predict stock price under conditions of market stability. If everything remains stable then the financial ratios will act as a good tool to predict stock Price.

\section{Literature Review}

Kendal (1953) explored whether historical data could be used to forecast future trends of prices. He explained dividend yield ratio, price earnings ratio and later extended to other variables like spread and interest rate and concluded that past sequence of price movements could not be used to predict future trends.

Beaver, (1996) examined the financial ratios can predict the future uncertainty. He concluded that if financial ratios can play a major part in predicting failure then it can also predict the stock price patterns and trends. He suggested that not all ratios are good predictors of stock returns. Liquid ratio and debt ratio is weak in terms of their predictive power.

Cochrane (1997) explained that dividend per share and dividend yield can forecast growth of stock price.

Lewellan (2004) concluded that the financial ratios are still considered a good indicator for determining the company's stock price in the future. The study extensively used earning per share to dividend per share and price earnings ratio to predict stock price and concluded that ratios are still useful in predicting stock price.

Kelly and McNamara (2008) examined the relationship between the performances of investment in Australian common stock in the industrial sector and their Price earnings ratio. The findings confirmed that the price earnings ratio has no effect in the Australian stock market.

Taani \& Banykhaled (2011) described the positive relationship between earning per share, return on equity and the capital market. The stock market had a significant effect on stock trading volume. The several accounting scandals and information may affect the stock return and market price of the stock.

Fun \& Basana (2011) examined the data of 45 companies listed on Indonesia stock exchange and found no signs of a relationship between the price-earnings ratio and the stock returns.

Menike \& Prabath (2014) explored the relation between accounting variable ratios and the stock price on a sample of 100 companies listed on the Colombo stock exchange. Applying the simple and multiple regression analysis, the authors concluded that ratios had a substantial and a positive impact on the stock prices and earnings per share has less effect on stock prices in the Colombo Stock Exchange. Also, Book value per share and dividend per share showed a positive effect on the stock price.

Sattar, et.al (2017) examined 13 commercial banks listed on Amman stock exchange, UAE, the primary objective of financial ratios in predicting the stock price. The research applied linear regression with multiple variables to find a relationship between financial ratios and stock price.

Ghimire \& Mishra (2018) examined the eleven financial and non-financial firms of NEPSE, Nepal, 
during the period 2012-2017. He concluded that the relationship between stock price and explanatory variables e.g. DPS, EPS, $\mathrm{P} / \mathrm{E}$ ratio, $\mathrm{BPS}, \mathrm{M} / \mathrm{B}$ ratio. The predictors $\mathrm{M} / \mathrm{B}$ ratio, $\mathrm{P} / \mathrm{E}$ ratio, are significant determinants of stock price which affect the stock price. Similarly, DPS, and BPS had positive influence on stock price whereas EPS has minimum influence on the stock price listed in NEPSE.

\section{Theoretical Framework}

On the basis of literature review, the dependent variable may be market price per share (Stock Price) and independent variables are price-earnings ratio, earning per share, return on equity, dividend per share, and book value per share. The theoretical framework determines the dependent variable and independent variables.
Independent Variables
Dependent Variable

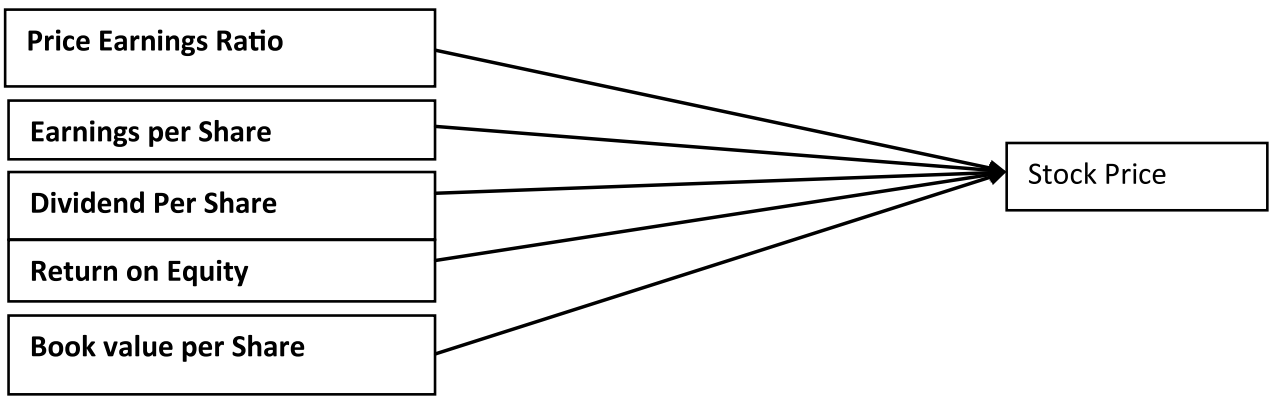

Hence, this has been used to analyze the independent variables as the predictor of the dependent variable.

\section{Research Hypothesis}

On the basis of literature review and theoretical frame work the following hypothesis have been developed.

H1a: There is a significant association between Price-Earnings ratio (P/E) as a predictor of Market Price per Share (MPS).

H1b: There is a significant association between Earning per share (EPS) as a predictor of Market Price per Share (MPS).

H1c: There is a significant association between Return on Equity (ROE) as a predictor of Market Price per Share (MPS).

H1d: There is a significant association between Dividends per Share (DPS) as a predictor of Market Price per Share (MPS).

H1e: There is a significant association between Book Value per Share (BVPS) as a predictor of Market Price per Share (MPS).

\section{Methodology}

The research methodology has been used to collect the data, analyze them, and draw a valid conclusion. This study is entirely based on secondary sources of data. The data has been collected from the NEPSE. The descriptive as well as analytical research designs have been used to analyze the sample. The data has been examined to determine the financial health of Nepalese commercial banks. Financial ratios help in predicting stock returns. The twenty-eight commercial banks listed on the Nepal Stock Exchange were selected as the sample. But the Rastriya Banijya Bank is government owned bank so; it is not taken as the sample in study. Hence, twenty-seven commercial banks are taken as the sample for the study. The information and data have been collected for the year 2065/066. The independent variables earnings per share, price- earnings ratio, dividend per share, return on equity and book value per share and the dependent 
variable is market price per share. The financial data have been collected from the financial statements of the sample banks and NEPSE.

The research follows the quantitative research design. The descriptive statistics, correlation coefficient, and multiple regression analysis are used to analyze the financial data and to draw the conclusion by testing the hypothesis. This will give the outlook of stock volatility and help understanding the general trend in the market for the year 2065/066. This will give clear indication about the trend of stock price and also explain the variability.

A correlation coefficient is done to find the multi-collinear relationship between the independent variables e.g. earnings per share, price-earnings ratio, return on equity, dividend per share, book value per share and the dependent variable the stock price (MPS). A correlation analysis is basically used to test the relationship between the independent and the dependent variable and is used for testing whether multicollinear relationship can be found between them. The final model used is step-wise multiple regression models, this model becomes helpful to find if the five selected financial ratios are good predictors of stock price or not. The model comprises ANOVA Table, Coefficient, Standard Error, t-stat and p-value. These models are examined and explained the independent variables. The three models Descriptive statistics, Correlation analysis and Regression model attempt to test the research objectives.

\section{Results and Findings}

\section{Descriptive Statistics}

Table 1

Descriptive Statistics

\begin{tabular}{|l|c|c|c|c|}
\hline Variables & Mean & S. D. & Minimum & Maximum \\
\hline Stock Price (MPS) & 357.22 & 174.263 & 148.00 & 836.00 \\
\hline Price Earnings Ratio (P/E) & 15.01 & 3.145 & 10.98 & 23.55 \\
\hline Earning Per Shares (EPS) & 23.49 & 8.508 & 7.46 & 47.21 \\
\hline Return On Equity (ROE) & 14.44 & 3.724 & 7.23 & 22.93 \\
\hline Dividend per Share (DPS) & 15.19 & 9.227 & 0.00 & 40.00 \\
\hline Book Value per Share (BPS) & 166.46 & 41.886 & 122.00 & 304.47 \\
\hline
\end{tabular}

This table describes the mean, standard deviation, minimum and maximum value for the independent variables e.g. price earnings ratio, earning per share, return on equity, dividend per share, and book value per share \& dependent variable stock price for 2065/066.

The mean stock price for the twenty-seven commercial banks is 357.22 and standard deviation is 174.263. The minimum stock price is 148 and maximum is 863 . The nine banks mean stock price is greater than average and rest eighteen banks' mean price is less than the average. This indicates that the most of the bank cannot attract to investors.

The price-earnings ratio has the mean of 15.01 and standard deviation of 3.145. A lower standard deviation than the mean indicates that the stock price has high variation e.g. minimum price earning variation from 10.98 to 23.55 . The $\mathrm{P} / \mathrm{E}$ ratio indicates that a stock is considered overvalued. The variation of $\mathrm{P} / \mathrm{E}$ ratio means that the investors are expecting higher earnings. The nine banks' $\mathrm{P} / \mathrm{E}$ ratio is greater than the mean value and rest eighteen banks' $\mathrm{P} / \mathrm{E}$ ratio is less than the average. It indicates that maximum banks cannot earn sufficient return.

The mean value for the earning per share is 23.49 and the standard deviation is compared to stock return is 8.508 . The minimum earning is 7.46 and maximum is 47.21 . The mean value of eleven banks is above the average and rest sixteen banks are below the average. This shows that the greater variation of stock earning encourage to the investors' for short sell the stock to realized the gains.

The mean value of ROE is 14.44 and the standard deviation is marginally low 3.724 . The minimum 
earning is 7.23 and maximum is 22.93 . The mean value of fourteen banks is greater and rest twelve banks below the mean value. This indicates that the half of the listed banks cannot earn sufficient income.

The mean value of dividend per share is 15.19 and standard deviation is 9.227. Similarly, the minimum DPS is zero but maximum is 40 . The mean value of thirteen banks above and rest fourteen banks' mean value is less than the average. The variation on DPS is higher among the commercial banks. A high dividend may attract the probable investors that can help to increase the stock price. Similarly, the stock's price is decreased those banks which pay fewer dividends.

The mean book value per share of commercial bank is 166.46 and standard deviation is 41.886 . The minimum BPS is 122 and maximum is 304.47. The mean value of nine commercial banks value is above the average and rest eighteen banks' mean value is less than the average. The BPS shows that most of the banks have not sufficient internal equity fund.

\section{Correlation Analysis}

This analysis is done to find the multi collinear relationship between the two variables and understand whether one variable has any impact on the other variable (Barndorff \& Shephard, 2004). It is calculated as follows:

The multi-collinear relationship will be analyzed to the stock price dependent variable and the Earning per share, Price Earnings ratio, Dividend per share, Return on Equity and Book value per share have correlation among themselves. For this the correlation table is constructed which is shown as below.

Table 2

\begin{tabular}{|c|c|c|c|c|c|c|c|}
\hline \multicolumn{8}{|c|}{ Correlations } \\
\hline & & Market Price & $\begin{array}{l}\text { Earning per } \\
\text { Share }\end{array}$ & $\begin{array}{c}\text { Return on } \\
\text { Equity }\end{array}$ & $\begin{array}{l}\text { Dividend per } \\
\text { Share }\end{array}$ & $\begin{array}{c}\text { Price Earning } \\
\text { Ratio }\end{array}$ & $\begin{array}{c}\text { Book Value } \\
\text { per Share }\end{array}$ \\
\hline \multirow[t]{3}{*}{ Market Price } & Pearson Correlation & 1 & $.895^{\pi \pi}$ & $.515^{\pi \pi}$ & $.585^{\pi \pi}$ & $.595^{\pi \pi}$ & $.572^{\pi x}$ \\
\hline & Sig. (2-tailed) & & .000 & .006 & .001 & .001 & .002 \\
\hline & $\mathrm{N}$ & 27 & 27 & 27 & 27 & 27 & 27 \\
\hline \multirow[t]{3}{*}{ Earning per Share } & Pearson Correlation & $.895^{x \times}$ & 1 & $.564^{\mathrm{xx}}$ & $.490^{x x}$ & .197 & $.726^{x \times}$ \\
\hline & Sig. (2-tailed) & .000 & & .002 & .009 & .325 & .000 \\
\hline & $N$ & 27 & 27 & 27 & 27 & 27 & 27 \\
\hline \multirow[t]{3}{*}{ Return on Equity } & Pearson Correlation & $.515^{\star \star}$ & $.564^{\pi \star}$ & 1 & .232 & .092 & .139 \\
\hline & Sig. (2-tailed) & .006 & .002 & & .243 & .649 & .490 \\
\hline & $\mathrm{N}$ & 27 & 27 & 27 & 27 & 27 & 27 \\
\hline \multirow[t]{3}{*}{ Dividend per Share } & Pearson Correlation & $.585^{x *}$ & $.490^{x \pi}$ & .232 & 1 & .355 & .265 \\
\hline & Sig. (2-tailed) & .001 & .009 & .243 & & .069 & .182 \\
\hline & $\mathrm{N}$ & 27 & 27 & 27 & 27 & 27 & 27 \\
\hline \multirow[t]{3}{*}{ Price Earning Ratio } & Pearson Correlation & $.595^{* \pi}$ & .197 & .092 & .355 & 1 & .040 \\
\hline & Sig. (2-tailed) & .001 & .325 & .649 & .069 & & .845 \\
\hline & $N$ & 27 & 27 & 27 & 27 & 27 & 27 \\
\hline \multirow[t]{3}{*}{ Book Value per Share } & Pearson Correlation & $.572^{x \star}$ & $.726^{x \star}$ & .139 & .265 & .040 & 1 \\
\hline & Sig. (2-tailed) & .002 & .000 & .490 & .182 & .845 & \\
\hline & $\mathrm{N}$ & 27 & 27 & 27 & 27 & 27 & 27 \\
\hline
\end{tabular}

The correlation among the variables ROE, DPS, P/E ratio and BPS have average correlation with market price but EPS is higher positive correlation. The positive correlation of 0.895 is found between EPS and Stock Price. The general trend in the selected variables has positive relation with the stock price. There is no multi-collinear between the variables. As per the Ratner (2009), a correlation of above 0.90 is considered of having a multi-collinear relationship. This analysis was done to explore the relationship among the independent variables and the stock price.

\section{Regression Analysis}

Regression analysis is considered extremely important in the research which compares two variables and show if one variable has the predictable ability to predict another variable. "Regression analysis is usage of statistical technique for organizing as to which variable can indeed have an impact" (Gallo, 2015). 
Silver Jubilee Issue - 2019

The p-value and t-value will give the exact results to prove the hypothesis. These will be deeply explored in this analysis. The Enter multiple regression models is calculated at first and then stepwise multiple regression method is used to identify the predictors as follows:

$$
\mathrm{Y}=\beta \mathrm{o}+\beta 1 \mathrm{X} 1+\beta 2 \mathrm{X} 2+\beta 3 \mathrm{X} 3+\beta 4 \mathrm{X} 4+\beta 5 \mathrm{X} 5+\varepsilon \mathrm{i}
$$

$\mathrm{Y}=$ the variable which is being predicted i.e. the Dependent Variable

$\mathrm{X} 1, \mathrm{X} 2, \mathrm{X} 3, \mathrm{X} 4$ and X5 = The variable that is being used to predict i.e. The Independent variable $\beta \mathrm{o}=$ Intercept

$\beta 1, \beta 2, \beta 3, \beta 4$, and $\beta 5=$ Coefficient of independent variables or slopes of independent variables $\varepsilon \mathrm{i}=$ the regression residuals or error terms.

Table 3

The multiple regression analysis (Enter method) is used to measure the independent variables and dependent variable to determine the statistically significant or not.

Model Summary ${ }^{\mathrm{b}}$

\begin{tabular}{|l|l|r|r|r|}
\hline Model & $\mathrm{R}$ & $\mathrm{R}$ Square & $\begin{array}{c}\text { Adjusted } \mathrm{R} \\
\text { Square }\end{array}$ & $\begin{array}{c}\text { Std. Error of } \\
\text { the Estimate }\end{array}$ \\
\hline 1 & $.994^{\mathrm{a}}$ & .988 & .985 & 21.45589 \\
\hline
\end{tabular}

a. Predictors: (Constant), Book value per Share, Price Earning

Ratio, Return on Equity, Dividend per Share, Earning per Share

b. Dependent Variable: Market Price per Share

ANOVAa

\begin{tabular}{|rl|r|r|r|r|r|}
\hline \multicolumn{1}{|c|}{} & \multicolumn{1}{c|}{$\begin{array}{c}\text { Sum of } \\
\text { Model }\end{array}$} & \multicolumn{1}{c|}{ Squares } & df & Mean Square & \multicolumn{1}{c|}{ F } & Sig. \\
\hline 1 & Regression & 779891.211 & 5 & 155978.242 & 338.822 & $.000^{\mathrm{b}}$ \\
& Residual & 9667.456 & 21 & 460.355 & & \\
& Total & 789558.667 & 26 & & & \\
\hline
\end{tabular}

a. Dependent Variable: Market Price per Share

b. Predictors: (Constant), Book value per Share, Price Earning Ratio, Return on Equity, Dividend per Share, Earning per Share

Coefficients $^{\mathrm{a}}$

\begin{tabular}{|c|c|c|c|c|c|c|c|c|}
\hline \multirow[b]{2}{*}{ Mode } & & \multicolumn{2}{|c|}{ Unstandardized Coefficients } & \multirow{2}{*}{$\begin{array}{c}\text { Standardized } \\
\text { Coefficients } \\
\text { Beta }\end{array}$} & \multirow[b]{2}{*}{$t$} & \multirow[b]{2}{*}{ Sig. } & \multicolumn{2}{|c|}{ Collinearity Statistics } \\
\hline & & $B$ & Std. Error & & & & Tolerance & VIF \\
\hline 1 & (Constant) & -363.856 & 34.774 & & -10.463 & .000 & & \\
\hline & Earning per Share & 17.115 & 1.096 & .836 & 15.609 & .000 & .203 & 4.915 \\
\hline & Return on Equity & .191 & 1.581 & .004 & .121 & .905 & .511 & 1.957 \\
\hline & Dividend per Share & .800 & .557 & .042 & 1.436 & .166 & .671 & 1.491 \\
\hline & Price Earning Ratio & 23.171 & 1.445 & .418 & 16.036 & .000 & .857 & 1.166 \\
\hline & Book value per Share & -263 & .171 & .063 & -1.532 & .140 & .343 & 2.912 \\
\hline
\end{tabular}

a. DependentVariable: Market Price per Share

The stepwise multiple regression analysis is used to identify the strong predictive power of independent variables to the dependent variables: 


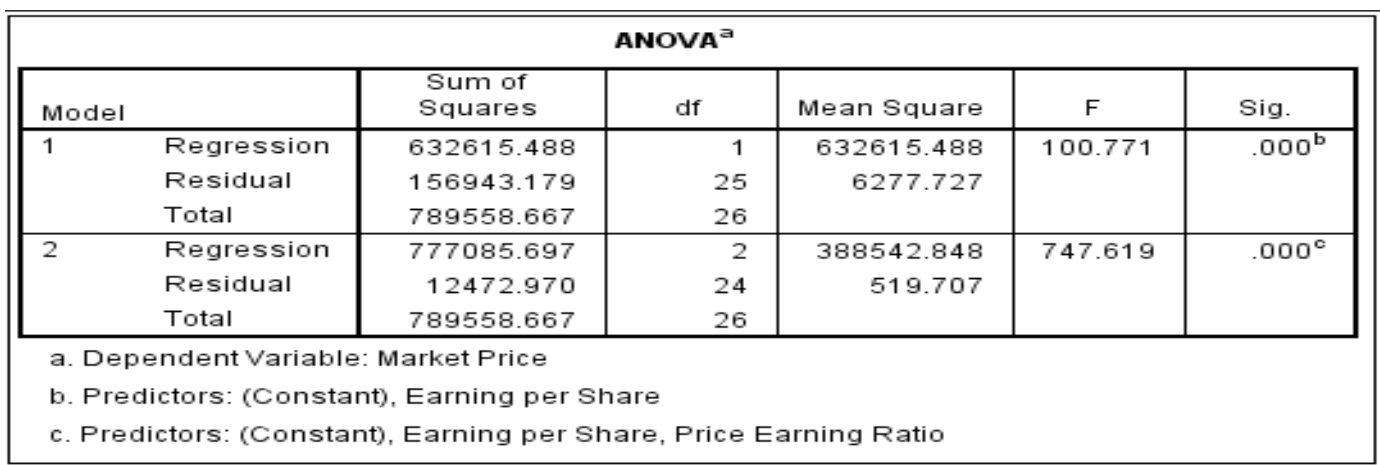

\begin{tabular}{|c|c|c|c|c|c|c|c|c|}
\hline \multicolumn{9}{|c|}{ Coefficients $^{a}$} \\
\hline \multirow[b]{2}{*}{ Model } & & \multicolumn{2}{|c|}{ Unstandardized Coefficients } & \multirow{2}{*}{$\begin{array}{c}\begin{array}{c}\text { Standardized } \\
\text { Coefficients }\end{array} \\
\text { Beta }\end{array}$} & \multirow[b]{2}{*}{$\mathrm{t}$} & \multirow[b]{2}{*}{ Sig. } & \multicolumn{2}{|c|}{ Collinearity Statistics } \\
\hline & & $B$ & Std. Error & & & & Tolerance & VIF \\
\hline \multirow[t]{2}{*}{1} & (Constant) & -73.414 & 45.528 & & -1.613 & .119 & & \\
\hline & Earning per Share & 18.333 & 1.826 & .895 & 10.038 & .000 & 1.000 & 1.000 \\
\hline \multirow[t]{3}{*}{2} & (Constant) & -395.054 & 23.318 & & -16.942 & .000 & & \\
\hline & Earning per Share & 16.576 & .536 & .809 & 30.928 & .000 & .961 & 1.040 \\
\hline & Price Earning Ratio & 24.174 & 1.450 & .436 & 16.673 & .000 & .961 & 1.040 \\
\hline
\end{tabular}

a. Dependent Variable: Market Price

ANOVA test is used to find the results of data analysis are significant or not (Satorra \& Bentler, 2001). The df represents the degree of freedom. DF for regression is 5 that are ' $\mathrm{k}$ ' it implies that there are five independent variables. The Residual $\mathrm{df}$ is $\mathrm{N}-\mathrm{k}-1$ i.e. no. of observations minus ' $\mathrm{k}$ ' minus 1 which gives $27-5-1=21$, "F ratio is the variation between the groups divided by the variation within the group the larger F value indicates more difference between the groups than within the group" Kim (2014). The F-value is 747.619 only EPS and P/E Ratio greater than the critical value it indicates that there are differences between the groups. The p-value of F- statistics $0.000<0.001$ hence the model is highly statistically significant. The confidence level for this research was 99 percent. But the stepwise multiple regression of ANOVA table shows that other independent variables e.g. ROE, DPS, and BPS are not statistically significant..

\section{Discussion}

The Test statistics measures the relationship between the sample data and its hypothesis. Since, the stock Price is very volatile and changes randomly. The test statistics have enough information from the sample data and power to reject the hypothesis. When the test statistics value is too high the $\mathrm{p}$ value is very low, a high t statistics and low $\mathrm{P}$ value indicates to accept the alternative hypothesis. The higher the $\mathrm{t}$-value indicates that there is significant association between financial ratios as a predictor of stock price in listed commercial banks in NEPSE. Hence, a high t-statistics value and lower p-value $<0.01$ can be used to predict stock price. As per the ANOVA table of multiple regression equation stepwise method indicate that two hypothesis. P/E ratio and EPS should be accepted as significantly strong predictor and other hypothesis should not be accepted. This indicates that if 1 percent increase in P/E ratio and EPS the positively impact on the market price per share by 16.576 percent and 24.174 percent respectively.

H1a: There is significant association between Price-Earnings ratio $(\mathrm{P} / \mathrm{E})$ as a predictor of Market Price per Share (MPS). Accepted

H1b: There is significant association between Earning per share (EPS) as a predictor of Market Price per Share (MPS). Accepted

H1c: There is significant association between Return on Equity (ROE) as a predictor of Market Price per Share (MPS). Rejected

H1d: There is significant association between Dividends per Share (DPS) as a predictor of Market Price per Share (MPS). Rejected

H1e: There is significant association between Book Value per Share (BVPS) as a predictor of Market Price per Share (MPS). Rejected 


\section{Conclusion}

This research was conducted for examining whether financial variables can predict the stock price for twenty seven commercial banks listed in the NEPSE. In this research five independent variables were used e.g. Price earnings ratio, Earning per Share, Dividend per Share, Return on Equity, and Book value per Share with the dependent variable stock Price. The descriptive statistics, correlation analysis and multiple regression models is used to prove empirically. These models are used as a strong tool to establish and find if the relationship or correlation exists between the variables. This research also throws light on the ratios can help to predict the stock return for the next year. Results give a clear indication that the P/E Ratio and EPS have the positive impact on the stock price in the NEPSE. Hence, the Nepalese investors can rely on the Price Earnings Ratio and the Earning per Share to predict the Market Price per Share. Hence, the overall conclusion of the research is that the financial variables direct the investors in NEPSE. If the answer is yes investors can rely on $\mathrm{P} / \mathrm{E}$ ratio and EPS on the confidence level is 99 percent and significance level is below 0.01 which gives clear indication that Price Earnings Ratio and Earning per Share in NEPSE.

\section{References}

Barndorff, O.E. \& Shephard, N., (2004). Econometric analysis of realized co-variation: High frequency based on the covariance and its impact, regression, and correlation in financial economics. Econometrics, 72(3), pp.885-925.

Beaver, William H. (1996). Financial Ratios as Predictors of Failure. Journal of Accounting Research, 4, 71-111.

Cochrane, J. H. (1997). Where is the market going? Uncertain facts and novel theories. NBER working paper series.

Ferris, Erin. (2018). Dividend Taxes and Stock Volatility. International Tax and Public Finance, 25(2), 377-403.

Fun, L.P. \& Basana, S.R. (2011). Price Earnings Ratio and Stock Return Analysis. Doctoral dissertation, PetraChristian University.

Gallo, A. (2015). A refresher on Regression Analysis. Harvard business review. PP. 43-49.

Kelly, S., McClean, J. \& McNamara, R. (2008). The low P/E effect and abnormal returns for Australian industrial firms.

Kendall, M. G., \& A. Bradford Hill. (1953). The Analysis of Economic Time-Series-Part I: Prices. Journal of the Royal Statistical Society. Series A (General), 116(1), 11-34. JSTOR,

Lewellen, J. (2004). Predicting returns with financial ratios. Journal of Financial Economics.pp. 209-235.

Kim, H.Y. (2014). Analysis of variance (ANOVA) comparing means of more than two dentistry \& endodontics, 39(1), 74-77

Menike, M. \& Prabath, S. (2014). The impact of accounting variables on stock price: Evidence from the Colombo stock exchange, Sri Lanka. International Journal of Business and Management, 9(5), 125.

Ratner, B., 2009. The correlation coefficient: Its values range between+1/- 1, or do they? Journal of targeting, measurement and analysis for marketing, 17(2), 139-142.

Satorra, A. and Bentler, P.M., (2001). A scaled difference chi-square test statistic for moment structure analysis. Psychometrika, 66(4), 507-514.

Sattar, et, al. (2017). Analysis of the Role of Fundamental Financial Ratios in Predicting the Stock Returns for Commercial Banks Listed on Amman Stock Exchange. Journal of Finance and Accounting, 8(1), $1-16$.

Taani, K. \& Banykhaled, A. 2011. The effect of financial ratios, firm size and cash flows from operating activities on earnings per share: International journal of social sciences and humanity studies, 3(1), 197-205. 
Appendix - 1

\begin{tabular}{|l|l|c|c|c|c|c|c|}
\hline S.N. & Name & MPS & EPS & P/E & DPS & ROE & BPS \\
\hline & Mean Value & 357.2 & 23.49 & 15.01 & 15.19 & 14.44 & 166.46 \\
\hline 1 & NABIL & 836 & 47.21 & 17.71 & 34.00 & 19.28 & 242.38 \\
\hline 2 & SCB & 680 & 28.87 & 23.55 & 17.50 & 17.14 & 177.18 \\
\hline 3 & EBL & 666 & 36.33 & 18.33 & 20.00 & 15.13 & 203.79 \\
\hline 4 & HBL & 576 & 31.25 & 18.72 & 15.78 & 17.31 & 179.17 \\
\hline 5 & NIB & 536 & 27.17 & 19.73 & 40.00 & 16.05 & 199.20 \\
\hline 6 & NICA & 480 & 34.36 & 13.97 & 10.53 & 22.93 & 161.74 \\
\hline 7 & N-SBI & 478 & 25.26 & 18.92 & 15.79 & 14.72 & 159.56 \\
\hline 8 & ADB & 421 & 32.27 & 12.87 & 21.05 & 9.26 & 241.54 \\
\hline 9 & NMB & 382 & 22.89 & 16.69 & 30.00 & 12.61 & 174.22 \\
\hline 10 & SANIMA & 357 & 26.25 & 13.60 & 14.00 & 18.36 & 135.09 \\
\hline 11 & NBL & 335 & 30.52 & 10.98 & 00.00 & 12.43 & 304.47 \\
\hline 12 & SBL & 334 & 23.90 & 13.97 & 13.16 & 14.90 & 162.57 \\
\hline 13 & PCBL & 310 & 22.15 & 14.00 & 16.00 & 19.38 & 150.41 \\
\hline 14 & GBIME & 306 & 24.21 & 12.64 & 16.00 & 14.66 & 149.72 \\
\hline 15 & PRVU & 278 & 21.77 & 12.77 & 08.42 & 18.28 & 164.95 \\
\hline 16 & BOK & 272 & 19.92 & 13.65 & 25.00 & 11.87 & 159.92 \\
\hline 17 & MBL & 270 & 20.54 & 13.15 & 10.00 & 13.83 & 128.57 \\
\hline 18 & NCCB & 262 & 22.11 & 11.85 & 16.84 & 19.56 & 174.66 \\
\hline 19 & SRBL & 256 & 20.05 & 12.77 & 11.50 & 11.16 & 144.55 \\
\hline 20 & CZBIL & 225 & 17.04 & 13.20 & 05.27 & 15.04 & 143.84 \\
\hline 21 & NBB & 224 & 18.82 & 11.90 & 10.53 & 09.94 & 148.10 \\
\hline 22 & LBL & 220 & 15.39 & 14.29 & 08.95 & 09.83 & 135.20 \\
\hline 23 & KBL & 218 & 15.40 & 14.16 & 08.50 & 12.66 & 150.12 \\
\hline 24 & JBNL & 209 & 17.06 & 12.25 & 22.90 & 12.45 & 129.70 \\
\hline 25 & MEGA & 197 & 15.43 & 12.72 & 07.85 & 12.36 & 125.95 \\
\hline 26 & CCBL & 169 & 09.87 & 17.12 & 06.50 & 11.60 & 124.86 \\
\hline 27 & CBL & 148 & 07.46 & 19.84 & 04.05 & 07.23 & 122.69 \\
\hline
\end{tabular}


